\title{
TCOM \\ How advertising and sustainability dialog in Pan-Amazonia: the perspective of advertising professionals in Peru and Brazil
}

\section{Marcio David Macedo da Silva and Ligia Terezinha Lopes Simonian}

\begin{abstract}
In this article it is investigated the relationship between advertising and sustainability by evaluating the perceptions of employees of advertising agencies in the Pan-Amazon region using pre-defined indicators. Seeking to identify the level of environmental practices adopted by advertising agencies toward the goal of building a sustainable society, it was interviewed advertising professionals about whether they saw themselves as contributing to changing consumer society towards a new society based on economic efficiency, social equality and ecological equilibrium. To answer these questions it was used quantitative survey data complemented by qualitative research using in-depth interviews. Results suggest that, from the point of view of advertising professionals, advertising agencies do not have much interest in contributing to a more sustainable society. Moreover, our research showed how the lack of strong ties within advertising trade associations further contribute to the weakness of efforts aimed at this area.
\end{abstract}

Keywords Environmental communication

Pan-Amazônia and sustainable advertising
Research into the relationship between sustainability and advertising is hardly new, and many studies have already been published based on content analysis of advertising pieces and the point of view of consumers [see Cabestré, Graziadei and Polesel Filho, 2013; Amaral Filho, 2008; Amaral Filho, 2010; Costa, 2006]. However a literature survey encountered no published academic research approaching these questions addressed to advertising professionals. This article is thus doubly relevant, first for investigating the opinions of advertising professionals regarding sustainability, and second, for carrying out the study in the Amazon region, namely, the cities of Belem and Manaus in the Brazilian Amazon and Iquitos and Tarapoto in Peru.

In this sense, sustainable advertising can be understood as a reaction to consumers' changing demands in relation to global brand positioning in the contemporary context. In this study, Souza's [2014, p. 306], definition of sustainable advertising as: 
about the socioenvironmental sustainability during all phases of creation, production, assembly and use of products and services, highlighting forms of re-use, recycling and discard of packaging and solid residues, and emphasizing potential risks to human and environmental health.

The so-called "ecologically correct" behavior has required companies to reevaluate their production procedures and especially their market position.

This study aims to document and understand the perception of advertising professionals employed by ad agencies in the Pan-Amazon region, and discuss the results from the point of view of sustainability. The study also sought to identify and characterize those agencies that do not demonstrate an understanding of sustainable practices, and suggest how adopting such practices might help them in the prioritizing strategic actions. Even in agencies where sustainable practices have already been incorporated for some time, it is useful to reinforce these practices towards the goal of sustainable development.

The overall objective was to identify to what degree sustainable practices are adopted by advertising agencies in Pan-Amazonia toward the construction of a sustainable society. Additional objectives include: 1 ) verify how sustainable practices are presented in advertising agencies; 2 ) which concepts and practices of sustainability are most frequently adopted by advertising agencies in the region. In this sense, the study seeks to answer the following question: are advertising professionals able to dialog with and contribute to changes in consumer society towards a new society built on economic efficiency, social equality and ecological equilibrium?

The research is significant in documenting how advertising professionals in the Pan-Amazon region perceive sustainability practices in the agencies where they work. It also seeks to document how Amazonian advertisers understand their work, and what they perceive as the barriers and opportunities to making personal and professionals contributions to a more sustainable world. This is probably one of the first academic studies to relate sustainability to the advertisement industry from the point of view of advertising professionals of the Pan-Amazon region.

This study uses the strategies of quantitative surveys and questionnaire-based interviews, following Malhotra [2001], Marconi and Lakatos [1996], Mattar [1996] and Perin et al. [2002]. To complement and better interpret the quantitative data from an interdisciplinary perspective, qualitative interview techniques were also used, following Bauer, Gaskell and Allum [2002] and Minayo [1993]. Thus the goal is to provide a critical distance from the routine methods of analysis, social circles, symbols and values that construct human relationships within the advertising industry.

It was initially sought to identify advertising agencies through professional trade associations, such as Sindicato Nacional das Agências de Propaganda (SINAPRO), in Brazil, and Asociación Peruana de Agencias de Publicidad (APAP). However the latter trade association had no agencies mentioned for cities in the Peruvian Amazon, so it was resorted to web searches using the key words "advertising agencies in Iquitos" and "advertising agencies in Tarapoto." 
Thus the sample was non-random, based on stratified types. For this reason, it was used descriptive statistics to analyze the numerical data which is classified, in the total 32 advertising professionals responded to the questionnaire of whom five also participated in in-depth interviews, then, the data were and organized in tables and graphics. Interpretive analysis was applied to relate the chosen categories, namely, sustainability and advertising. Face-to-face questionnaires and in-depth interviews were carried out in the studied cities to better appreciate the perceptions of advertising professionals in the region.

Still, data were categorized according to five domains, pre-defined by the author based on his own professional experience as well as literature review about indicators of sustainability such as those developed by the Associação Brasileira das Agências de Publicidade (ABAP), the Instituto Ethos and the Advertising Standards Authority (ASA). The five dimensions chosen are: View of sustainability, Socio-environmentally responsible advertising, Relationship with advertising clients, Involvement in socio-environmental actions, and Consumer style.

The first four dimensions refer to the behaviour of advertising agencies, in view of its employees, for the actions taken on sustainability in their policies and routines: use of sustainable materials such as cups, papers, re-usable ink and commercial partnership with suppliers who use also sustainable products, services, training and capacity-building. The fifth dimension aims to verify how individuals relate to the issue of sustainability in their day-to-day and practices adopt to contribute to the reduction of waste, in their roles as citizens, homeowners, consumers, parents between others, for example, the use of recycled material, planned purchasing, economical usage of water and energy.

To facilitate the understanding of the results, were created, finally, four indicators: strong, medium, weak and indifferent to evaluate each dimension in relation to more or less sustainable activity in the pan-Amazonian agencies. The indicators were developed based on discussions between the author and the director of the graduate program and junior company in Statistics of the Federal University of Para (UFPA), who was responsible for developing, tabulating and statistical analysis of the indicator results, divided in the following categories: up to $25 \%$ indifferent; $26 \%-50 \%$ weak; $51 \%-75 \%$ medium; and $76 \%-100 \%$ strong.

Table 1 presents the sample of advertising agencies included in the study; per the request of most of these agencies, anonymity is maintained.

Table 1. Advertising agencies identified for the study. Source: Silva [2014].

\begin{tabular}{|l|l|l|}
\hline \multirow{2}{*}{ Brasil } & Amazonas - Manaus & 5 agencies \\
\cline { 2 - 3 } & Pará - Belém & 6 agencies \\
\hline \multirow{2}{*}{ Peru } & Loreto - Iquitos & 2 agencies \\
\cline { 2 - 3 } & San Martin - Tarapoto & 3 agencies \\
\hline
\end{tabular}

Norms of the Associação Brasileira de Normas Técnicas (ABNT) were adopted, interpreted in accordance with the observations and recommendations of Condurú and Pereira [2006]. Data were stored in an Excel spread sheet and analyzed using Statistical Package for the Social Sciences — SPSS, Ver.20.0 (demo). 
The article first presents a brief overview of the synergies and contradictions between advertising and sustainability, from the global level to the Pan-Amazonian context. Then follows a brief discussion about the communications sector, specifically advertising, and its adoption of the precepts of sustainable development. And too follows a presentation and a discussion of the research results, shedding light on the individual and collective thoughts of advertising professionals in the Pan-Amazon region regarding sustainable practices.

\section{Advertising and sustainability: a critical perspective}

The concern about sustainability was previously restricted to the debates of environmentalists and research scientists. However, more recently it has become a subject of more general public life, inevitably leading to interactions between the realm of communications and the discourses around sustainability. This popularization arose mostly through the activism of non-government organizations and the dissemination through the media of polemical topics such as genetically modified organisms, urban pollution, threats to freshwater supply, global warming, and so on.

Such is its importance and current relevance that the topic was highlighted during the World Social Forum in 2006; and mainly with discussions about the crucial role of communications in contemporary society and the collaborative relations with corporations, governments, organizations of civil society and advertising agencies. During this forum, both communication in the broad sense, and advertising more specifically were discussed as central elements in helping to integrate civil society, non-government organizations, government and business in the promotion and dissemination of corporate socio-environmental development.

The question has become one of strategic importance, as pointed out by Pereira and Herschmann [2003, p. 1],

\section{[...] due to the central role occupied by the management of ever more complex and integrated flows of information, meaning and knowledge, both from the point of view of sociocultural dynamics generally and from the point of view of the processes of production specifically.}

This relationship is becoming increasingly interdependent due especially to the attitudes adopted by younger consumers, demanding and paying more attention to planetary well-being.

There is sustainability in advertising, with its stressed importance and their reported missing, but the conceptual rigor is often ignored by professionals working in media companies, including the advertising agencies. But the problem is decoupling message and reality that advertising campaigns broadcast daily to millions of potential consumers affected by its contents. The use of the concept of sustainable consumption, which functions as tensioning alternative in the logic of capital interests is seen often only as a synonym for reducing environmental impacts.

In addition, as set by Santos [2006], its meaning encompasses a broader commitment to future generations and the reduction of social inequality from a 
redistributive justice policy. Contrary to planned obsolescence, the concept of sustainable consumption stimulates recycling and reuse of waste production, use of clean technologies, use of packaging and biodegradable products and using renewable resources intelligently. So, when trying to build an image of sustainability in their activities, some companies end up practicing through their advertising agencies, the greenwashing of commercial and industrial activities.

Sustainable development and advertising are both themes of growing global interest, and recently the two have had increasingly frequent interactions in public debate and daily life. Discussions about sustainability have gained increasing visibility among citizens and have become the subject of all forms of social communication, including advertising. And yet even though many are exposed to the theme of sustainability, most people maintain their prior consumption habits, and indeed, few people are exposed to newer, more sustainable modes of consumption in the media.

To illustrate the importance of advertising companies in contributing to changing consumption habits and stimulating new modes of consumption, some agencies have shown how they can change their own habits of advertising production while maintaining profitability. The English advertising agency CURB has developed advertising campaigns using materials based on the principal of minimal environmental impact. CURB has developed a singular, surprising, creative style to provide media visibility to its clients by imprinting logos in public spaces using only natural materials and processes such as pruning shrubbery, sand sculpture, selective power-washing of sidewalks or marking trees with sunlight (see Figure 1).

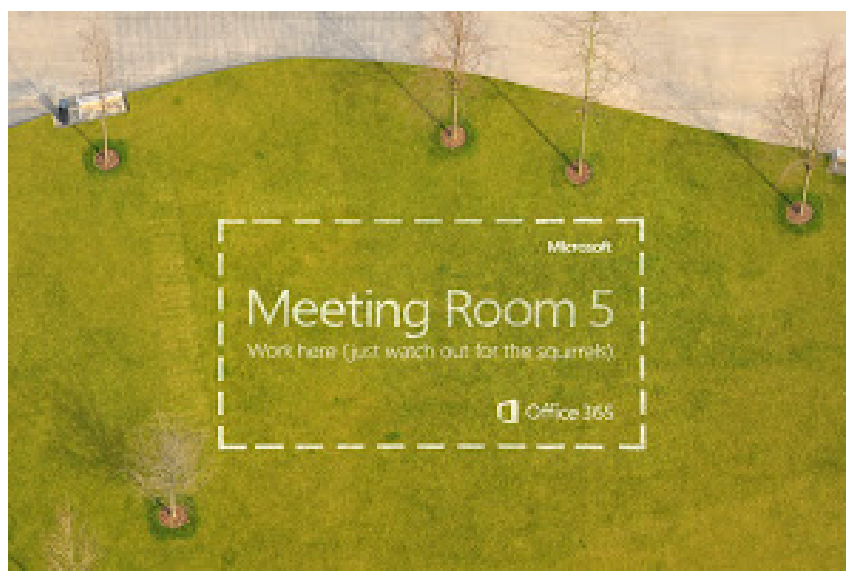

Figure 1. CURB advertisement in a London park for the launch of a Microsoft product.

Over the past two decades the concept of sustainability has consolidated itself through company policies disseminated through advertising and corporate communications. Over the past ten years, the ways of communicating these themes has changed radically, opening the way for companies like CURB to become, not the exception, but the rule in terms of sustainable advertising practices. Given the attention being paid by society to these themes, company discourses and good practices require specialized and consistent communication strategies. 


\subsection{Sustainability and Amazonia}

Amazonia as a geographical and ecological region that is divided among various countries, results in diverse "Amazonias" particular to each nation while also sharing many characteristics across national borders [Aragón, 2005]. Indeed, as pointed by Dominguez [1987], Amazonia has been defined according to at least three different sets of factors: the river basin itself, the ecosystem, and legal and political systems and boundaries.

These overlapping and sometimes contradictory definitions have resulted, for example, in variable estimates of the region's land mass, ranging from $7,350,621 \mathrm{Km}^{2}$ [CDEA, 1992] to $6,869,344 \mathrm{Km}^{2}$ [Dominguez, 1987], with other estimates of 7 million [O desafio amazônico] and 7.5 million $\mathrm{Km}^{2}$ [Braga et al., 1999]. In this article, as pointed by Aragón [2005, p. 1], when one talks about Pan-Amazonia, he or she is "[...] referring to a unique region shared among several countries, breaking the persistent myth that Amazonia is only Brazilian".

In terms of its value for communications, Amaral Filho [2010, p. 21], notes that Amazonia
[...] is a brand that carries with it other meanings that involve the concrete possibilities of environmental protection, biodiversity, sustainable development, wildlife, traditional populations, and a symbolic value that comes from these various concrete elements, and for this very reason, a much more emotional value that expresses these meanings from the perspective of a global culture that appropriates cultural values in order transform them into commodities, the term used here in the fantastical, "fetishistic," used by Marx.

It was within this region, damaged by the negative effects of a way of life based on high levels of production and consumption, thatwe sought to understand the attitudes of advertising professionals towards sustainability.

Much has been said about advertising and sustainability, a concept of such great importance and yet widely recognized to be lacking. And yet professionals in the communication industry, including advertising, rarely approach the concept with the needed conceptual rigor. The problem is in the dissociation between media messages and the reality that advertising campaigns transmit daily to millions of consumers who could be potentially influenced by these contents.

The concept of sustainable consumption, which would appear to function as an alternative to the interests of capital, is often used merely as a synonym for reducing environmental impacts. As pointed out by Santos [2006], the meaning of sustainability includes a broader commitment to future generations and the reduction of social inequality through redistribute justice. Contrary to the trend towards planned obsolescence, the concept of sustainable consumption would stimulate recycling and reuse of production residues, employ clean technologies, adopt biodegradable products and packaging and promote more rational use of renewable resources.

Instead, according to CONAR [2012], while trying to promote an image of sustainability for their clients, some advertising agencies engage in 
"greenwashing" of commercial and industrial activities. And that are in fact not as positive for the environment as the media campaigns make them seem.

Concerns over resource sustainability and the future of humanity first emerged in the $18^{\text {th }}$ century [see Corrêa, 1998; Dias, 2004; Franco and Drummond, 2009]. More effective actions in this direction were stimulated by the Club of Rome meetings beginning in the late 1960s. In the 1990s, the idea emerged that it was plausible to reconcile environmental concerns with capitalist exploitation of nature. Since then, the notion of sustainable development has evolved, allied with other contested definitions within the domains of environment [Silva, 2014; Simonian, 2007; Zhouri, Laschefski and Paiva, 2005] and public policy, been used to justify the exploitation of territorialized natural resources.

In this process, private companies have re-examined their concepts, prioritizing and realizing new concepts in their mission statements, for example contributing towards a better world through their socio-environmentally responsible actions. Environmental concerns have come to the forefront of government institutions, corporations and social movements, creating motivation for developing new public policies at the national and international level. In this context, communications companies, and specifically advertising agencies are called upon to cooperate in developing concepts and implementing actions associated with sustainability and environmental preservation.

The concept of sustainable development immediately adapted itself to organizations that felt themselves obliged to take on more serious responsibilities in their relations with the environment. And yet they did not act entirely "voluntarily," since companies that had not addressed such concerns could find themselves forced to do so by government agencies or movements of civil society, which are ever more prominent protagonists in environmental defense. The pressure exerted by stakeholders can be clearly identified in the adoption of a series of indicators and evaluations, including the Indicador de Sustentabilidade Empresarial (ISE), the Dow Jones Sustainability Index (DJSI) and others.

\subsection{Pathways of communication}

For social scientists like Silva [2010, p. 83], "[...] communication is considered to be a constitutive action in the life of all individuals [... ]," and understanding the phenomenon is one of the main challenges of their research. According to Jensen [2008, p. 36], "[...] communication is part and parcel of the constant social work of coordination and confrontation, of microsocial and macrosocial structures." The construction and development of communications theory involved the direct collaboration of at least seven disciplines: rhetoric, phenomenology, cybernetics, social psychology, sociocultural theory and critical theory.

Advertising techniques are usually associated with more general communication strategies, focusing on the relationship Company — Product/Service - Public. Advertising, with its capacity to innovate new forms of communication and awaken new sensitivities desires plays an important role in the field of communication. In other words, as a "communicator," the advertising professional applies to publicity all the technologies and means of communication available in a given historical moment. 
Whereas concern about sustainability was previously restricted to the debates of environmentalists and research scientists, more recently it has become a subject of more general public life, inevitably leading to interactions between the realm of communications and the discourses around sustainability. This popularization arose mostly through the activism of non-government organizations and the dissemination through the media of polemical topics such as genetically modified organisms, urban pollution, threats to fresh water supply, global warming, and so on.

Such is its importance and current relevance that the topic was highlighted during the World Social Forum in 2006, with discussions about the crucial role of communications in contemporary society and the collaborative relations with corporations, governments, organizations of civil society and advertising agencies. During this forum, both communication in the broad sense, and advertising more specifically were discussed as central elements in helping to integrate civil society, non-government organizations, government and business in the promotion and dissemination of corporate socio-environmental development.

According to Silva, Simonian and Amaral Filho [2013, p. 1], "[...] advertising is both a sociocultural and economic phenomenon, fundamentally associated with modern society but with roots going back to ancient Classical times." The true origins of advertising and propaganda have been lost, but their evolution and development in modern times is associated with the emergence of industrial civilization; for a discussion of the similarities and differences between advertising and propaganda, see Camargo [2011]; Camargo [2013]; Rabaça and Barbosa [2001]; Sant'Anna [1999] and Durandin [1995]. In its process of evolution and maturation, advertising has become an important, controversial and dynamic part of consumer society in all its historical, social and political dimensions.

According to Giacomini Filho and Licht [2004, p. 44], "[...] all advertising announcements represent acts of intervention in society, thus conferring on the advertising sector broad responsibilities, including responsibilities that emanate from ethical postures." Even though they emerge within the logic of business, advertising can also be used for projects of public interest, involving socio-environmental themes and changes in consumption habits, both individual and collective.

In this perspective, it seems plausible that advertising campaigns could be used to raise public awareness and stimulate actions that promote environmental preservation, changing consumption habits and thus helping maintain the health of our planet. This does not mean that advertising has the sole responsibility for changing behaviour, but that, in conjunction with other strategies and projects, the advertising sector could represent an important ally in contributing to such changes.

Even though advertisements depend on the approval of the clients who pay for them, it is ultimately the audience which accepts or rejects their messages, such that, if society does not approve of a given message, the advertisement can end having effects contrary to their original intentions. Even though companies have their own private interests, they can still elaborate questions of public and environmental interest, contributing to the growing understanding that 
environmental preservation is an important issue that is integrated into the culture, and not separate from it.

In order for advertising campaigns to take advantage of the concept of socio-environmental responsibility to provoke critical reflections, or even change behaviour, they must somehow contribute to environmental preservation. Contents mediated by advertising and presented to the social imaginary, who emphasizes its role in the exercise of authority and power in collective life, represent meanings within the social sphere and reflect hegemonic positions within and beyond the environmental realm, including private interests.

Yet they can also pertain, as noted by Santos [2007, p. 47], “[...] to public interests in following the trend of environmental preservation, since this discussion generates pressure on people and institutions to view the environment in a new way." Advertising can be understood, in the sense discussed by Canevacci [2001], as an integral part of visual merchandise, and simultaneously both consequence and result of a network of economic, social, symbolic and political values.

When using contested notions in the environmental realm, advertising discourses reflect specific manners of signifying nature, at the same time as they help constitute new truths that discredit other possible meanings. Some examples of this tendencies include the concept of the balance between humans and nature, the essential nature of production, reconciliation between exploitation and preservation, respect towards future generations, sustainability, and so on. This to happen, a common global culture must be created and spread by media and entertainment conglomerates, stimulating the adoption of new habits of global conduct.

Interdisciplinary activity provides the necessary access to diverse techniques and scientific knowledge. In this manner, advertising agencies can take advantage of all they need to achieve their objectives, especially when sustainability is in question.

Publicity in Pan-Amazonia: Brazil and Peru
To understand the following bar graph, it must be emphasized that the statements found were the result of carrying out questionnaires and in-depth interviews with advertising professionals in Brazil and Peru. The more area shaded in blue in each bar, the more the interviewees' responses reflected the dimensions of sustainability analyzed. The more area shaded red, the less the interview results reflect these dimensions of sustainability. Interviews in advertising agencies in Belem and Manaus were carried out between May and October of 2013, and interviews in Iquitos and Tarapoto were carried out between March and July of 2014.

Figure 2 summarizes analysis of results regarding the perceptions of the Pan-Amazonian advertising professionals. The first four dimensions refer to the behaviour of advertising agencies with regard to questions of sustainability in their policies and routines, as perceived by their employees. The fifth dimension assesses how individuals relate to the question of sustainability in their daily lives, including the practices they adopt, in their roles as citizens, homeowners, and consumers, to reduce waste.

View of Sustainability (58.87\%), Involvement in Socio-environmental activities $(66.98 \%)$ and Relationship with advertising clients (57.73\%). Thus, advertising 


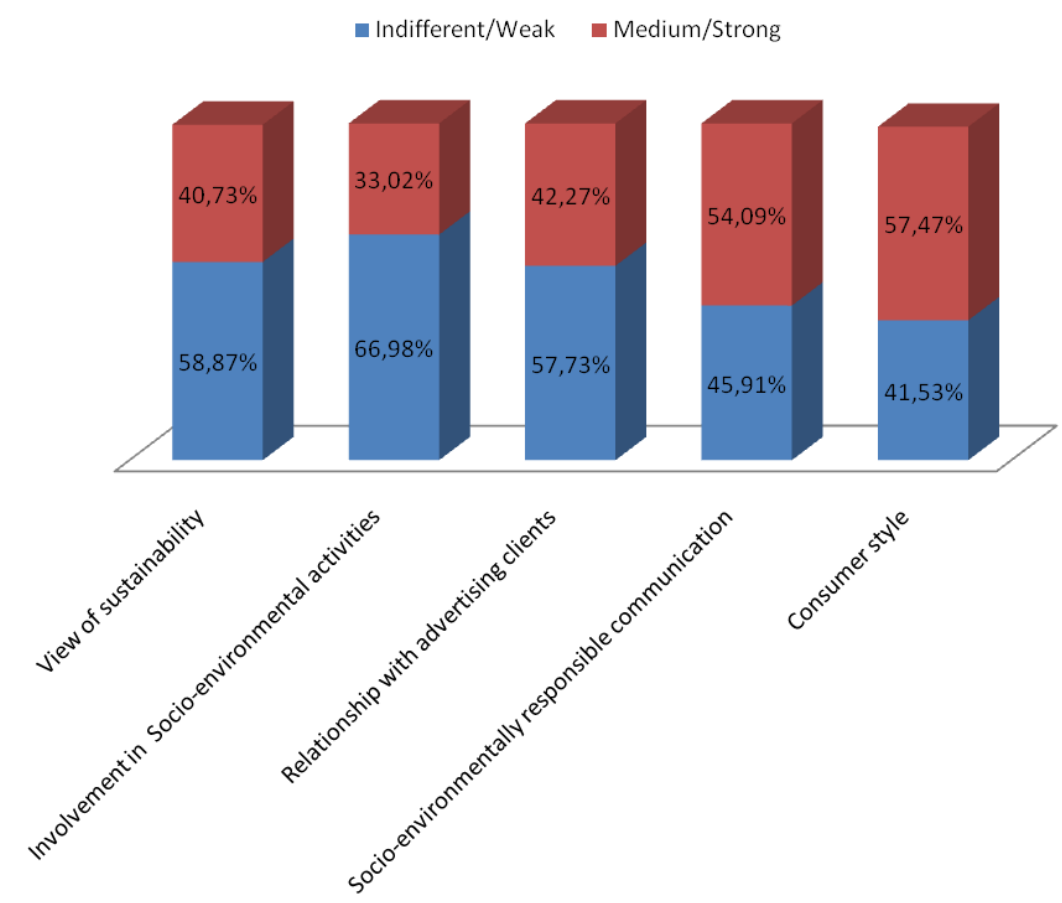

Figure 2. Results, Pan-Amazonian advertising professionals (Brazil, Peru). Source: Silva [2014].

professionals have a negative perception of the development of sustainable practices in the firms where they work. View of Sustainability andInvolvement in Socio-environmental activities stand out with the weakest evaluations, since these are the dimensions that most reflect the sustainable practices adopted within advertising agencies. By contrast Socio-environmentally responsible communication $(54.09 \%)$ and Consumer style $(57.47 \%)$ are the two that have their highest percentages in blue, in Medium/Strong indicators.

This is the dimension that sought to capture the level of sustainable practices incorporated by advertising professionals in their daily lives, both personal and professional. Thus, it is clear that sustainable attitudes adopted by professional individually occur with greater frequency than the practices implemented by advertising agencies in the Pan-Amazon. Thus much work remains to be done before advertising agencies in the Pan-Amazon region incorporate and internalize sustainability concepts into their policies, mission and values.

This movement needs to be put in place so that advertising agencies move beyond stimulating the current patterns of consumerism. Despite the fact that the advertising agencies under study are located in the Amazon, little difference was their marketing strategies, when compared to those found in advertising agencies located in urban areas far from such region.

When checking the results found the size sustainability vision, it can be inferred that most advertising agencies still have a long way until they internalize in their policies, missions and values, notions and concepts of sustainability. As an illustration of these results, the statement by Advertising Professional No. 1 [Belém, 2013] was significant: "There is a language of sustainability in use, but I'm not sure if this is a solution, and I'm not sure if there is really a problem to solve." 
Indeed, in the world of advertising, no one thinks or is even allowed to think about a society that consumes and spends less natural or monetary resources: a model of consumption that takes into consideration a balanced life for future generations is entirely ignored. This idea is perceived as utopian (after More [1516]), and yet as Rothstein, Muschamp and Marty [2003] point out, humanity has shown that it is possible to dial back consumption patterns that appear to be leading us towards collapse and chaos.

About the size involvement in socio-environmental activities, the perception of respondents is somewhat more forceful about not realize little or no importance given by advertising agencies to sustainability actions in their daily lives and also in relation to its partners, clients and suppliers. The Advertising Professional No. 14 [Iquitos, 2014] stated, "Well, there are advertising campaigns que have come from other regions and other countries have been very successful in promoting environmental consciousness, but what is needed is support for the local entrepreneurs and suppliers to develop environmental consciousness. However, there is still a need to promote environmental awareness. Is it in need of more campaigns that have this component, right?"

With regard to the dimension Involvement in Socio-environmental activities, again the advertising professionals overwhelmingly agree $(66.98 \%)$ that the advertising agencies where they work do not place great importance on such actions either in their own activities or in their relationship with their own business partners and suppliers. This is a worrisome trend showing a lack of integration among various actors, since changes in behaviour require stimulus from various sectors. With regard to the dimension of relationship with clients, most of those interviewed $(57.73 \%)$ do not see any effort on behalf of advertising agencies to develop criteria for choosing and evaluating sustainable practices of their clients.

Symptomatic of this issue was a comment by Advertising Professional No. 5 [Belém, 2013]:

\begin{abstract}
Here in our agency we don't have much of a discourse about being an agency of sustainable management. What we do is save on paper. It's not our role to stimulate and incentivize consumers to be more conscious about their consumption. We make our living by responding to our clients' demands, I'm not sure to what degree the clients are concerned with this. We think a lot about persuading the client to buy, but not to by conscientiously.
\end{abstract}

Without stimulus for adopting such criteria, the development of new attitudes towards sustainability is likely to remain weak. This tendency is further weakened by the lack of any trade association that unites advertising agencies located in these four Amazonian cities.

For the dimension Socio-environmentally responsible communication, our intention was to verify whether advertising agencies were involved in building sustainable practices with their partners and suppliers. For $54.09 \%$ of those interviewed, there was a perception that criteria of sustainability are taken into consideration when choosing suppliers and service contracts. However, the degree of agreement was barely over half, showing that much remains to be done to stimulate the long-term adoption of sustainable practices. 
With regard to the dimension of Consumer style, the only that evaluated the sustainable attitudes of those interviewed, the highest level of agreement was found $(57.47 \%)$. Although this result suggests that there is some degree of environmental consciousness among advertising professionals, it does not indicate any trend towards a rapid transition towards more sustainable habits. The result was corroborated in interviews showing how individuals were increasingly concerned with adopting sustainable habits in their private and professional life.

Discussion and prospects for ongoing work
This study did not set out to take on the entire reality surrounding attitudes toward sustainability in Pan-Amazonian advertising, nor to take the research results as absolute truths. However by carrying out research in the two largest cities in the Brazilian Amazon, and the two largest in the Peruvian Amazon, one can assume that similar, if not identical, modes of thinking and acting would be found in the advertising sectors of other Pan-Amazonian cities.

It was sought to investigate a little-explored relationship between sustainability and advertising from the point of view of advertising professionals active in this field in Pan-Amazonia. Generally speaking, the results point to little interest on behalf of advertising agencies in carrying out proactive changes that place sustainability at the center of their policies.

It was found little evidence of regular, voluntary or even compulsory participation of advertising agencies in socio-environmental actions with clients, business partners or NGOs. Although some of the advertising professionals themselves are involved in such activities, such as buying sustainable and reusable products, taking care to not waste electricity, especially those in the Peruvian Amazon, the quantitative results suggest a need for more and better campaigns, discussions and internal policies in advertising agencies; and this around the question of sustainable practices in the daily routines of advertising agencies, their business partners and clients.

The questions asked to advertising professionals included: whether their agencies carried out training and capacity building for sustainability; whether they developed actions in partnership with clients; choices about suppliers who adopted sustainable practices; and awareness of environmental impacts.

The main objective of the research was to identify the level of sustainable practices adopted by advertising agencies, and it was found that these practices are still far from adequate implementation in a systematic and continuous fashion in this sector. A lack of Pan-Amazonian trade organizations in the advertising sector detected throughout this study appears to contribute significantly to the fragmentation and lack of dissemination of sustainability concepts. For the Brazilian Amazon, only Belem had a trade association that congregated the advertising sector. In the Peruvian Amazon by contrast, no such trade association was found, and none of the advertising agencies identified were listed by the Asociación Peruana de Agencias de Publicidad, based in Lima.

Results suggest that the advertising agencies have little effective interest in practices contributing to a more sustainable society. Even though economic forces tend to reinforce the stimulation of exaggerated consumption, advertising agencies 
do have the power to influence their clients in these matters. This conclusion was corroborated in the comment made by Advertising Professional No. 21 [Iquitos, 2014]: "The agencies here today don't think about developing advertising as a whole, the only interest is in the money, just their own work. They only think about personal gain, not about developing the profession collectively." However in the case at hand, they apparently do not exercise this influence.

For Simonian [2007, p. 36], “[...] what we observe are widely disseminated media and analytic productions with a triumphalist orientation, but no productive realities that can be verified." Instead there appears to be seems to an almost magical fusion between sustainable development, environmental preservation and resource extraction that feeds the industry of consumption. Especially in Pan-Amazonia, the advertising sector has an inherent duty to transmit ethical and accurate messages, capable of educating consumers to be more environmentally and socially conscious.

In choosing indicators and dimensions for study, it was sought to bring the concept of sustainability to the professional practice which these agencies should know best: communication. Advertising agencies working within the model of sustainability should consider the impact of its processes and products both on the environment and within society. Advertising agencies in Pan-Amazonia need to develop a culture of sustainability practices and help stimulate its employees to update their knowledge of the subject, keeping in mind that advertising does not exist just in and of itself. Giving greater support for meeting the criteria of sustainable is a tremendous, however viable challenge for advertising agencies.

It is widely known that all aspects of consumption impact the environment, and there is already a consensus that these problems must be addressed through sustainable practices. This involves not only the rational use of resources, but rethinking larger economic, social and cultural processes. This is the most fragile element in developing sustainable advertising: rapidly increasing decision-making capacity such that the agencies work in a more focused manner, clients have greater confidence that their money is well invested, and consumers are not surrounded by irrelevant advertising that only increases visual and other kinds of pollution without any real benefit.

The Pan-Amazon advertising industry retains the capacity, tools and conditions to contribute to changes in the consumer society and to various other industries, based on economic efficiency, social equality and ecological balance. In all circumstances, it is up to the persons responsible for the advertising agencies themselves to develop activities on sustainable, balanced and rational development. Companies based in the Pan-Amazon region shall thus have the opportunity to create a competitive edge for themselves and for the entire region, inspiring additional viewpoints on the matter through strategies undertaken by the Pan-Amazon advertising industry. 
Amaral Filho, O. (2008). 'Marca Amazônia: uma promessa publicitária para fidelização de consumidores nos mercados globais'. Doutorado em Desenvolvimento Sustentável. Tese. Belém, Brasil: Universidade Federal do Pará, p. 412.

- (2010). 'Amazônia versus meio ambiente: sedutoras armadilhas discursivas da mídia para fidelizar novos consumidores'. In: Pesquisa em comunicação na Amazônia. Ed. by Amaral Filho, O., Castro, F. F. de and Seixas, N. S. dos A. Belém, Brasil: FADESP, pp. 19-43.

Aragón, E. (2005). Ciência e educação superior na Amazônia: desafios e oportunidades de cooperação internacional. Belém, Brasil: UNAMAZ - NAEA.

Bauer, M. W., Gaskell, S. and Allum, N. C. (2002). 'Qualidade, quantidade e interesses do conhecimento: evitando confusões'. In: Bauer, M. W. and Gaskell, N. C. Pesquisa qualitativa com texto, imagem e som: um manual prático. Petrópolis, Brazil: Vozes, pp. 17-36.

Belém (9th June 2013). Entrevista concedida para a tese Publicidade e Sustentabilidade: um diálogo possível?! Uma visão crítica do pensamento de publicitários pan-amazônida.

Braga, B. et al. (1999). 'Sustainable water-resources development of the Amazon Basin'. In: Management of Latin American Rivers Basin: Amazon, Plata and São Francisco. Ed. by A. K. Biswas et al. Tokyo, Japan: United Nations University Press.

Branco, S. M. O desafio amazônico. São Paulo, Brasil.

Cabestré, S., Graziadei, T. and Polesel Filho, P. (2013). 'Comunicação estratégica, sustentabilidade e responsabilidade socioambiental: um estudo destacando os aspectos teórico-conceituais e práticos'. In: Congresso Brasileiro de Ciências da Comunicação, 41. URL: http://www . intercom.org. br/papers/nacionais/2008 /resumos/R3-0877-1.pdf (visited on 1st March 2013).

Camargo, H. W. de. (2011). 'Linguagem e mito no filme publicitário'. Doutorado em Estudos da Linguagem. Londrina, Brasil: Universidade Estadual de Londrina.

- (2013). Mito e filme publicitário: estruturas de significação. Londrina, Brasil: EDUEL.

Canevacci, M. (2001). Antropologia da comunicação visual. Rio de Janeiro, Brasil: DP\&A.

CDEA, Commission on Development and Environment for Amazonia (1992). Amazonia without myths. Washington, D.C., U.S.A.: IDB/UNDP/ACT.

CONAR (2012). Conselho Nacional de Autorregulamentação Publicitária. URL: http: //www . conar.org. br/ (visited on 1st April 2012).

Condurú, M. T. and Pereira, J. A. R. (2006). Elaboração de trabalhos acadêmicos: normas, critérios e procedimentos. 2nd ed. Belém, Brasil: NUMA; UFPA; EDUFPA.

Corrêa, L. B. C. G. (1998). Comércio e meio ambiente. Brasília, DF, Brasil: Instituto Rio Branco.

Costa, L. M. (2006). Comunicação \& meio ambiente: a análise das campanhas de prevenção a incêndios florestais na Amazônia. 1st ed. Belém, Brasil: EDUFPA; NAEA.

Dias, G. F. (2004). Educação ambiental: princípios e práticas. São Paulo, Brasil: Gaia. Dominguez, C. (1987). 'Colombia y la Pan-Amazonia'. In: Universidad Nacional de Colombia. Colombia Amazónica. Bogotá, DE, Brasil: FEN Colombia, pp. 33-54.

Durandin, G. (1995). La mentira en la propaganda política y en la publicidad. Barcelona, Spain: Paidós.

Franco, J. L. and Drummond, J. A. (2009). Proteção à natureza e identidade nacional no Brasil: anos 1920-1940. Rio de Janeiro, Brasil: Fiocruz. 
Giacomini Filho, G. and Licht, R. H. G. (2004). 'Cultura organizacional e meio ambiente na perspectiva publicitária'. IMES 20 (58): Administração, São Caetano do Sul, pp. 5-12.

Iquitos (September 2014). Entrevista concedida para a tese Publicidade e Sustentabilidade: um diálogo possível?! Uma visão crítica do pensamento de publicitários pan-amazônidas.

Jensen, K. B. (2008). 'Teoria e filosofia da comunicação'. Matrizes 2 (1), pp. 31-47.

Malhotra, N. (2001). Pesquisa de marketing: uma orientação aplicada. 3rd ed. Porto Alegre, Brasil: Bookman.

Marconi, M. de. A. and Lakatos, E. M. (1996). Técnicas de pesquisa: planejamento e execução de pesquisas, amostragens e técnicas de pesquisas, elaboração análise e interpretação de dados. 3rd ed. São Paulo, Brasil: Atlas.

Mattar, F. N. (1996). Pesquisa de marketing: metodologia, planejamento. 3rd ed. São Paulo, Brasil: Atlas.

Minayo, M. C. de. S. (1993). O desafio do conhecimento. São Paulo, Brasil: Hucitec.

More, T. (1516). Utopia. Edição preparada por Logan, G. M. and Adams, R. M.; tradução Camargo, J. L. and Cipolla, M. B. (1993). São Paulo, Brasil: Martins Fontes.

Pereira, C. A. M. and Herschmann, M. (2003). 'Comunicação, cultura e gestão de organizações privadas e públicas na perspectiva do desenvolvimento local sustentável'. In: Congresso Brasileiro de Ciências da Comunicação. (Belo Horizonte, Brazil, 2nd-6th September 2003). Sociedade Brasileira de Estudos Interdisciplinares da Comunicação.

Perin, M. G. et al. (2002). 'A pesquisa Survey em artigos de marketing nos ENANPAD's da década de 90'. RIMAR, Revista Interdisciplinar de Marketing 1 (1), pp. 44-59.

Rabaça, C. A. and Barbosa, G. (2001). Dicionário de comunicação: nova edição revista e atualizada. Rio de Janeiro, Brasil: Campus.

Rothstein, E., Muschamp, H. and Marty, M. E. (2003). Visions of utopia. Oxford, U.K.: Oxford University Press.

Sant'Anna, A. (1999). A propaganda: teoria, técnica e prática. São Paulo: Pioneira.

Santos, B. de. S. (2006). A globalização e as ciências sociais. São Paulo, Brasil: Cortez.

Santos, L. L. dos (2007). ‘Comunicação e consumo sustentável: das entrelinhas do capitalismo leve ao enquadramento da sustentabilidade na mídia'. Fronteiras estudos midiáticos 7 (3). URL:

http://revistas. unisinos.br/index.php/fronteiras/article/view/6395.

Silva, M. D. M. da. (2014). 'Publicidade e sustentabilidade: um diálogo possível? Uma visão crítica do pensamento de publicitários pan-amazônidas'. Doutorado em Desenvolvimento Sustentável do Trópico úmido. Belèm, Brasil: Universidade Federal do Pará.

Silva, M. D. M. da., Simonian, L. T. L. and Amaral Filho, O. (2013). 'A publicidade e a definição de regras quanto ao uso do conceito de sustentabilidade'. Razón y Palabra 85, pp. 1-22. URL: http: //www. redalyc .org/articulo.oa?id=199531506054.

Silva, S. A. B. da (2010). Estética utilitária: interação através da experiência sensível com a publicidade. João Pessoa, Brasil: A União; EDUFPB.

Simonian, L. T. L. (2007). 'Tendências recentes quanto à sustentabilidade no uso dos recursos naturais pelas populações tradicionais amazônidas'. In: População e meio ambiente na pan-Amazônia. Ed. by L. E. Aragón-Vaca. Belém, Brasil: UFPA; NAEA; UNESCO, pp. 25-44. 
Souza, M. D. M. de (2014). 'Publicidade sustentável: fonte de informação e educação para o consumo consciente'. Em Tempo 13.

Zhouri, A. L. M., Laschefski, K. and Paiva, Â. (2005). 'Uma sociologia do licenciamento ambiental: o caso das hidrelétricas em Minas Gerais'. In: A insustentável leveza da política ambiental: desenvolvimento e con?itos socioambientais. 2010. Ed. by A. L. M. Zhouri, K. Laschefski and D. P. Barros. Belo Horizonte, Brasil: Autêntica, pp. 89-116.

Marcio David Macedo da Silva: doctor in Sciences of Sustainable Development at the Graduate Program in Sustainable Development of the Humid Tropics (PPGDSTU), in the Nucleous of Amazonian High Studies (NAEA), of the Federal University of Para (UFPA). M. Sc. in Communication and Languages ot the Tuiuti University of Parana (UTP/PR). Specialist in Corporate Communication (Catholic University of Paraná; PUC/PR). Graduated in Social Communication - emphasis in Advertising by the UFPA. Experience in Media, mainly operating in the following areas: Social Causes' Advertising, Advertising Policy, Third Sector, Social Responsibility and Market Research. E-mail: mdmacedos@yahoo.com.br.

Ligia Terezinha Lopes Simonian: Ph. D. in Anthropology (City University of New York (CUNY); 1993) and post-doctorate in the same University (2000); M. Sc. in Social Anthropology (Federal University of Rio de Janeiro (UFRJ); 1981); Specialization in Anthropology (Museum of Anthropology of the Federal University of Santa Catarina (UFSC); 1973). Undergraduate Studies in History (Federal University of Santa Maria (UFSM); 1972) and in Law (Faculty of Law of Santo Angelo; 1975); Associate Professor, Level 4, in the Nucleous of Amazonian High Studies (NAEA)/Federal University of Para (UFPA), where she teaches and advises thesis and dissertations in two Graduate Programs. Her major interests are in Anthropology of Development, Interdisciplinary Methodology, Public Policy, Management, Sustainable Development, Tourism, Biosociodiversity, Traditional Populations, Women, International Frontiers; she also works with Image and Photography; her main research area is the Pan-Amazon.

E-mail: simonianl@gmail.com.

How to cite

Silva, M. D. M. da and Simonian, L. T. L. (2016). 'How advertising and sustainability dialog in Pan-Amazonia: the perspective of advertising professionals in Peru and Brazil'. JCOM 15 (05), A01. 